\title{
Bioflok sebagai Solusi Mengatasi Permasalahan Lingkungan untuk Akuakultur Masa Depan Berkelanjutan : Sebuah Tinjauan
}

\section{(Biofloc as A Solution in Overcoming Environmental Problems for Sustainable Future Aquaculture : A Review)}

\author{
Rini Marlida \\ Prodi Budidaya Perairan, Fakultas Pertanian, Universitas Achmad Yani Banjarmasin \\ email: rinimarlida@uay.ac.id
}

\begin{abstract}
ABSTRAK
Akuakultur saat ini menjadi tumpuan penyedia protein hewani dunia. Keberlanjutan sektor ini sangat dipengaruhi oleh tata kelola usaha yang mesti mengedepankan aspek ramah lingkungan. Limbah pengayaan nutrient dan merebaknya penyakit ikan dan organisme akuatik lainnya secara signifikan menjadi isu yang hadir dalam sistem akuakultur di seluruh dunia saat ini, khususnya akuakultur intensif. Tujuan penulisan artikel ini adalah untuk memberikan tinjauan mengenai bioflok sebagai solusi dalam mengatasi permasalahan lingkungan untuk akuakultur masa depan yang berkelanjutan. Akuakultur intensif menerapkan pemeliharaan dengan tingkat kepadatan tinggi dan pemberian pakan buatan. Sistem tersebut bermuara pada masalah lingkungan karena sejumlah besar limbah yang dihasilkan mengandung padatan dan nutrient yang terakumulasi menjadi polutan penyebab eutrofikasi dan racun bagi organisme akuatik. Teknologi bioflok merupakan pendekatan baru untuk mengurangi limbah kegiatan akuakultur. Pada sistem ini, bakteri heterotroph dan alga ditumbuhkan bersama-sama dalam flok dibawah kondisi terkontrol dengan tanpa atau pertukaran air minimal. Bioflok merupakan paket nutrient yang bisa di manfaatkan langsung oleh hewan budidaya. Bioflok juga berperan sebagai biokontrol. Teknologi bioflok dapat membantu mengatasi permasalahan dalam akuakultur intensif.
\end{abstract}

Kata kunci: Akuakultur bioflok, ramah lingkungan.

\section{ABSTRACT}

Aquaculture is currently the foundation of the world's animal protein provider. The sustainability of this sector is greatly influenced by business governance which must prioritize environmentally friendly aspects. Nutrient enrichment waste and the spread of fish and other aquatic organisms are significant issues present in aquaculture systems throughout the world today, especially intensive aquaculture. The purpose of writing this article is to provide an overview of biofloc as a solution in overcoming environmental problems for a sustainable future aquaculture. Intensive aquaculture applies high density maintenance and artificial feeding. The system leads to environmental problems because a large amount of waste produced contains solids and nutrients that accumulate into pollutants that cause eutrophication and toxins for aquatic organisms. Biofloc technology is a new approach to reduce the waste of aquaculture activities. In this system, heterotrophic bacteria and algae are grown together in flocks under controlled conditions with no or minimal water exchange. Biofloc is a nutrient package that can be utilized directly by farm animals. Biofloc also acts as biocontrol. Biofloc technology can help overcome problems in intensive aquaculture.

Keywords: Aquaculture, biofloc, environmentally friendly.

Article History Submitted: April 11, 2020 Accepted: May 27, 2020
Approved with minor revision: May 4, 2020

Published: May 31, 2020

\section{PENDAHULUAN}

Akuakultur merupakan suatu kegiatan ekonomi yang cukup menjanjikan dalam hal mengangkat harkat kehidupan dan pemenuhan zat gizi masyarakat terutama sumber protein hewani. Konsumsi ikan dunia per kapita meningkat dari 9,0 $\mathrm{kg}$ pada tahun 1961 menjadi 20,2 kg pada tahun 2015 dengan peningkatan rata-rata $1,5 \%$ per tahun (FAO 2018). Intensifikasi akuakultur dan globalisasi perdagangan hasil laut dunia 
telah mencapai perkembangan yang luar biasa dalam industri akuakultur. FAO (2018), menjelaskan bahwa produksi ikan dunia meningkat 171 juta ton pada tahun 2016, dimana $47 \%$ dari total produksi tersebut dihasilkan oleh akuakultur. Menurut Gutierez-Wing dan Malone (2006), pertumbuhan akuakultur diperlukan agar dapat memenuhi kebutuhan nutrisi protein bagi manusia terutama bagi negara-negara berkembang,

Sejak budidaya udang intensif membutuhkan input pakan pellet yang tinggi, bahan kimia dan obat-obatan, serta manajemen yang tidak tepat telah menyebabkan masalah lingkungan yang kompleks termasuk penyakit, degradasi lingkungan, dan akumulasi sedimen dari endapan lumpur hitam pada tanah dasar kolam (Nimrat et. al., 2008). Hal ini akan berdampak serius secara ekonomi karena munculnya penyakit dan penurunan kualitas lingkungan.

Budidaya intensif dengan padat tebar tinggi membutuhkan jumlah pakan tinggi yang masuk ke dalam sistem. Hal ini menyebabkan kualitas air menurun karena meningkatnya konsentrasi metabolit (Avnimelech 2007). Hanya $20-30 \%$ dari nutrisi pakan dikonversi menjadi biomassa ikan (panen), selebihnya terakumulasi di perairan sebagai pakan terbuang dan produk ekskresi (Avnimelech and Ritvo, 2003). Konsekuensi dari penerapan pakan dengan protein tinggi akan memproduksi ammonia $\left(\mathrm{NH}_{3}\right)$ yang tinggi dari produk ekskresi dari species budidaya dan produk mineralisasi dari bakteri. Ammonia yang berada diatas ambang akan bersifat toksik bagi organisme.

"Nutrient rich out flow" dan "diseases outbreaks" secara signifikan menjadi issue yang hadir dalam sistem akuakultur di seluruh dunia saat ini. Pada budidaya intensif dengan pertukaran air minimal atau tanpa pertukaran air terdapat komunitas mikroba dapat dikelola menjadi bioflok dan memiliki kontribusi dalam pemeliharaan kualitas air dan sumber nutrisi bagi organisme budidaya. Tujuan penulisan artikel ini adalah untuk memberikan tinjauan mengenai bioflok sebagai solusi dalam mengatasi permasalahan lingkungan untuk akuakultur masa depan yang berkelanjutan.

\section{MENGAPA BIOFLOK ?}

Prinsip dasar pada teknologi bioflok adalah mengubah senyawa organik dan anorganik pada siklus nitrogen sistem akuakultur melalui stimulasi pertumbuhan mikroba heterotrofik yang mampu mengasimilasi limbah nitrogen dan mengkonversinya menjadi biomassa mikroba yang bisa dimanfaatkan organisme akuatik sebagai sumber pakan. Sistem akuakultur intensif dengan teknologi bioflok sangat tergantung pada struktur komunitas organisme mikro yang ada di dalamnya. Komunitas mikrobial tersebut dibentuk oleh susunan mikroorganisme yang heterogen seperti plankton baik fitoplankton maupun zooplankton, bakteri (floc former dan filamentous bacteria), agregat hidup, pemakan bakteri, partikel koloid, polimer organik, dan sel-sel mati (Avnimelech, 2007), partikel tersebut tersuspensi dengan propulsi air dan aerasi (Ray et. al., 2010), serta ukurannya dapat mencapai $1000 \mu \mathrm{m}$ (De Schryver et. al., 2008).

Formasi flok merupakan bentuk mekanisme adaptasi dari mikroba yang bertujuan untuk akuisisi pakan pada tingkat selular. Ukuran mikroba yang sangat kecil umumnya hanya berada pada bagian permukaan air dan kesulitan dalam memperoleh nutrisi, sehingga untuk mengatasi masalah tersebut bakteri cenderung tumbuh dalam bentuk agregat (microbial flocs). Menurut De Schryver et. al., (2008), bioflok memiliki keuntungan ekologis bagi mikroba, termasuk proteksi terhadap predator, akses nutrient, dan kebutuhan substrat. Hasil penelitian Lara et. al., (2017) menunjukan bahwa penggunaan blower di kolam budidaya akan memperbaiki formasi flok dan meningkatkan performa pertumbuhan udang Litopenaeus vannamei.

Teknologi bioflok merupakan pendekatan baru dalam mengatasi masalah akuakultur. Pada sistem ini alga dan bakteri heterotrofik dikultur bersama-sama untuk membentuk flok dalam kondisi terkontrol di 
kolam budidaya ikan dan udang. Teknologi ini berbasis pada pengolahan limbah domestik konvensional dengan istilah lumpur aktif (activated sludge) (De Schryver et. al., (2008). Aplikasi teknologi bioflok dalam sistem budidaya ikan ditujukan untuk meminimalkan pergantian air dan biosekuritas yang dapat menjamin keberlanjutan akuakultur intensif melalui manajemen pemberian pakan (Ahmad et. al., 2016). Sehingga penerapan teknologi bioflok menurut Ulloa Walker et. al., (2020), merupakan tool pada sistem budidaya intensif dengan pertukaran air minimal, meningkatkan daur ulang nutrient, dan memproduksi pakan alami secara in situ melalui pembentukan agregat tersuspensi (flok).

\section{MANAJEMEN KUALITAS LINGKUNGAN AKUAKULTUR}

Akuakultur intensif saat ini dihadapkan pada masalah lingkungan karena input pakan komersil dengan kandungan protein yang tinggi berdampak pada penurunan kualitas air di lingkungan budidaya. Padatan dan nutrient yang berasal dari pakan yang tidak termakan, feses, dan urea/ammonia hewan budidaya, jika tidak dikelola dengan benar dan dibuang langsung ke lingkungan dapat menjadi polutan yang mengakibatkan masalah seperti eutrofikasi dan racun bagi fauna akuatik. Secara alami terdapat tiga cara konversi nitrogen untuk membuang amoniak-nitrogen pada system akuakultur yaitu (a) pembuangan nitrogen secara fotoautotrofik oleh kelompok alga, (b) konversi ammoniak-nitrogen menjadi nitrat nitrogen yang dilakukan bakteri autotrof, dan (c) konversi secara langsung amoniak-nitrogen menjadi biomassa bakteri (Ebeling et. al., 2006). Melalui pengambilan ammonium oleh komunitas mikroba dan pengaturan rasio karbon-nitrogen $(\mathrm{C} / \mathrm{N})$ yang tinggi akumulasi nitrogen anorganik toksik dapat dihambat oleh sistem bioflok.

Crab et. al., (2007) menjelaskan bahwa teknologi bioflok merupakan teknik budidaya dimana kualitas air dikelola dan pakan bagi hewan budidaya secara simultan diproduksi dalam bentuk partikel flok.
Nitrifikasi pada sistem bioflok berlangsung ratusan kali lebih intensif dibanding dengan ssstem plankton. Bakteri pengoksidasi ammonium dan ammonia yakni Nitrosomonas dan Nitrobacter yang bersifat peka cahaya akan melindungi dirinya dalam struktur flok. Teknologi bioflok merupakan metode yang efektif dan berkelanjutan dalam memperbaiki kualitas air melalui penambahan sumber karbon ke kolam budidaya (Crab et. al., 2012).

Ray et. al., (2010) menunjukan bahwa produksi biomassa udang L.vannamei $\left(\mathrm{kg} \mathrm{m}^{-3}\right)$ meningkat $41 \%$ apabila konsentrasi bioflok dikelola dengan "external settling chambers" dan terjadi penurunan konsentrasi nitrat dan fosfat masing-masing sebesar $60 \%$ dan $61 \%$. Pemanfaatan berbagai sumber karbon untuk mereduksi TAN (total ammonia nitrogen) pada pemeliharaan udang L. vannamei dengan teknologi bioflok telah diteliti oleh Serra et. al., (2015), hasil yang diperoleh bahwa dekstose dan molase mampu mereduksi ammonia lebih cepat, efisien dalam membentuk flok dan memperbaiki kualitas air. Pemeliharaan kualitas air selama masa "overwintering" pada kolam Tilapia hybrid telah dilakukan oleh Crab et. al., (2009) dengan cara menambahkan pati (starch) untuk menstimulasi pembentukan flok. Penambahan pati atau meningkatkan sumber karbohidrat mampu membatasi pembentukan nitrogen inorganik yang bersifat toksik $\left(\mathrm{NH}_{4}, \mathrm{NO}_{2}\right)$ pada $\mathrm{C} / \mathrm{N} \mathrm{20}$, meskipun padat tebar tinggi $20 \mathrm{~kg} \cdot \mathrm{m}^{-3}$ pada panen akhir. Sementara Ekasari et. al., (2015), menambahkan molase (53\% C) C/N rasio 10 , setiap hari ke kolam pemeliharaan induk ikan nila (Oreochromis niloticus) dengan menggunakan teknologi bioflok mampu meningkatkan kualitas dan performa produksi larva maupun benih dibandingkan kontrol (tanpa bioflok).

\section{BIOFLOK DAN NUTRISI AKUAKULTUR}

Selain masalah lingkungan akuakultur intensif juga dihadapkan pada masalah rendahnya pemanfaatan pakan. 
Banyak pakan terbuang dan hilang sebagai feses dan berpotensi menjadi bahan limbah. Kandungan protein pakan yang tinggi meningkatkan buangan nitrogen yang tidak terkonversi dan bersifat toksik. Sementara komponen pakan pada budidaya udang meliputi $40-60 \%$ dari total biaya produksi (Bender et. al., 2004).

Bioflok merupakan paket nutrient dan protein mikroba yang bisa dimanfaatkan langsung sebagai sumber nutrisi ideal bagi hewan budidaya (Avnimelech, 2007; Emerenciano et. al., 2011). Sejumlah penelitian telah dilakukan dan menunjukan bahwa bioflok memiliki kontribusi secara nyata dalam meningkatkan pertumbuhan dan memperbaiki nilai konversi pakan pada ikan tilapia ( Ekasari et. al., 2015), ikan mas (Cyprinus carpio L.) (Najdegerami et. al.,, 2015), South American catfish (Rhamdia quelen) (Poli et. al.,, 2015), Labeo rohita (Ahmad et. al., 2016), udang L. vannamei (Dantas et. al., 2014; Khatoon et. al., 2016), udang galah (Macrobrachium rossenbergii) (Crab et. al., 2010a)

Bioflok memiliki dampak positif terhadap aktivitas enzim pencernaan dan laju pertumbuhan pada udang L. vannamei (Xu \& Pan, 2012). Selanjutnya dijelaskan bahwa terjadi peningkatan aktivitas enzim protease, amylase, selulase dan lipase melalui konsumsi bioflok.

Hasil penelitian Usman et. al., (2011) menunjukan bahwa ikan bandeng yang diberi pakan buatan sebanyak 2,5\% /hari dalam media bioflok dapat meningkatkan efisiensi pakan 58,5\% dan efisiensi pemanfaatan protein $59,2 \%$. Nilai nutrisi bioflok untuk hewan air sangat tergantung faktor ketersediaan pakan, kemampuan memakan dan mencerna, serta densitas dari partikel tersuspensi. Menurut hasil penelitian Azim \& Little (2008), pada ikan Tilapia menunjukan bahwa pemberikan pakan mengandung bioflok dengan kadar protein $35 \%$ menghasilkan berat akhir individu 9-10\% lebih tinggi dibandingkan kontrol, dengan nilai rasio konversi pakan

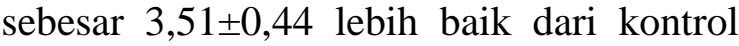
yakni 4,97 \pm 0,12. Demikian pula dengan hasil penelitian Dantas et. al., (2014), subtitusi tepung ikan dengan menggunakan tepung bioflok sebanyak $20 \%$ mampu meningkatkan pertumbuhan postlarva $L$. vannamei, sehingga diperoleh bahan pakan alternatif dengan biaya yang lebih efektif serta ramah lingkungan. Khatoon et. al., (2016) yang juga menggunakan hewan uji L.vannamei dengan pemberian pakan mengandung bioflok $50 \%$, menghasilkan laju pertumbuhan spesifik lebih tinggi jika dibandingkan dengan perlakuan pakan bioflok $75 \%$ dan $100 \%$ pakan komersial. Kuhn et. al., (2010) menjelaskan bahwa tepung bioflok merupakan sumber nutrient alternatif yang berbiaya murah dan berkelanjutan.

\section{BIOFLOK SEBAGAI BIOKONTROL}

Teknologi bioflok dapat digunakan sebagai biokontrol untuk infeksi bakteri di lingkungan akuakultur. Bakteri pembentuk flok (flocs forming bacteria) terdiri dari bakteri non pathogen yang memiliki kemampuan untuk mensintesis enzim ekstraseluller, memproduksi bakteriosin terhadap bakteri pathogen, dan mampu mengeluarkan metabolit sekunder yang menekan pertumbuahan dan menetralkan toksin dari plankton merugikan. Crab et. al., (2010b), telah meneliti mengenai kemampuan antimikrobial dan antipatogenik dari bioflok yang ditumbuhkan dalam glycerol terhadap pathogen Vibrio harveyi. Bioflok ternyata mampu menghambat sensiregulasi quorum dari bioluminescence $V$. harveyi. Bioflok secara signifikan meningkatkan kelangsungan hidup dari gnotobiotik larva brine shrimp (Artemia franciscana) pada uji tantang dengan $V$. harveyi. Bioflok mengandung senyawa immunostimulator karena teknologi bioflok berkaitan dengan sejumlah bakteri menguntungkan dan produk yang dihasilkannya dalam meningkat status imun organisme akuakultur (Crab et. al.,, 2012). Salah satunya adalah kemampuan akumulasi senyawa poly- $\beta$-hydroxybutyrate (PHB) dari bakteri yang bersinergi pada bioflok. PHB melindungi organisme budidaya dari infeksi bakteri penyebab penyakit. 
Hasil penelitian Ahmad et. al., (2016), menunjukan bahwa ikan Labeo rohita yang dipelihara dengan teknologi bioflok tanpa pergantian air yang diberi input tepung tapioka meningkatkan pertumbuhan dan respon imun non spesifik, setelah diuji tantang dengan bakteri pathogen Aeromonas hydrophila. Parameter respon imun non spesifik bawaan (non specific innate immune response) yang diukur adalah aktivitas respiratory burst, myeloperoxidase (MPO) dan aktivitas lysozyme. Sedangkan protein yang ternasuk element humoral dari system imun non spesifik adalah immunoglobulin, transferrin, dan agglutinin.

Ferreira et. al., (2015), berhasil mengisolasi sejumlah bakteri Bacillus dari flok yang terbentuk pada system budidaya L.vannamei super intensif. Uji secara in vitro secara nyata mampu menghambat pertumbuhan bakteri pathogen Vibrio alginolyticus. Selanjutnya Ferreira et. al., (2015), menyatakan bahwa Bacillus spp. yang diisolasi, sangat penting dalam pemeliharaan kesehatan dan pertumbuhan L.vannamei dan dapat digunakan sebagai probiotik atau biokontrol. Kuhn et. al., (2010), menerangkan bahwa L. vannamei yang dipelihara pada budidaya sistem bioflok lebih sehat dan tumbuh lebih cepat.

\section{KESIMPULAN}

Berdasarkan kajian pada tulisan ini dapat disimpulkan bahwa permasalahan lingkungan akuakultur yakni merebaknya penyakit dan penurunan kualitas lingkungan yang bermuara pada kegagalan produksi dan menyebabkan dilema pada sektor ini, dapat diatasi dengan metoda budidaya perikanan sistem bioflok. Teknologi bioflok melalui fungsi manajemen kualitas air, serta sebagai sumber nutrisi dan biokontrol, menjadi solusi dalam mengatasi permasalahan lingkungan untuk akuakultur masa depan yang berkelanjutan.

\section{DAFTAR PUSTAKA}

Ahmad, I. H., Verma, A.K., Rani, B. A. M., Rathore, G., Saharan, Neelam, Gora,
Hussain, A. (2016). Growth, nonspecific immunity and diseases resistance of Labeo rohita against Aeromonas hydrophila in biofloc system using different carbon sources. Aquaculture, 457, 61-67. https://doi.org/10.1016/j.aquaculture .2016 .02 .011

Avnimelech, Y., (2007). Feeding with microbial flocs by tilapia in minimal discharge bio-flocs technology ponds. Aquaculture, 264,140-147 https://doi.org/10.1016/j.aquaculture .2006 .11 .025

Avnimelech, Y. \& G. Ritvo, (2003). Shrimp and fish pond soils : processes and management. Aquaculture, 220, 549-567.

https://doi.org/10.1016/S0044-8486 (02)00641-5

Azim, M.E. \& Little, D.C., (2008). The biofloc technology (BFT) in indoor tanks: water quality, biofloc composition, and grwth and welfare of Nile tilapia (Oreochromis niloticus). Aquaculture, 283, 29-35. https://doi.org/10.1016/j.aquaculture .2008 .06 .036

Bender, J., Lee, R., Sheppard, M., Brinkley, K., Phillips, P., Yeboah, Y., Wah, R.C., (2004). A waste effluent treatment system based on microbial mats for black seabass Centropristis striata recycled water mariculture. Aquacultur Engineering, 31, 73-82. https://doi.org/10.1016/j.aquaeng.20 04.02.001

Crab, R., Avnimelech, Y., Defoirdt, T., Bossier, P., and Verstraete, W., (2007).Nitrogen removal techniques in aquaculture for a sustainable aquaculture. Aquaculture, 270, 1-14. https://doi.org/10.1016/j.aquaculture .2007 .05 .006

Crab, R., Kochva, M., Verstraete, W., Avnimelech, Y., (2009). Bioflocs 
technology application in overwintering of tilapia. Aquacultur Engineering 40, 105-112. https://doi.org/10.1016/j.aquaeng.20 08.12 .004

Crab, R., Chielens, B., Wille, M., Bossier, P., \& Verstraete, W. (2010). The effect of different carbon sources on the nutritional value of bioflocs, a feed for Macrobrachium rosenbergii postlarvae. Aquaculture Research, 4(4), 559-567. https://doi.org/10. 1111/j.1365-2109.2009.02353.x

Crab, R., Lambert, A., Defoirdt, T., Bossier, P., \& Verstraete, W. (2010). The application of bioflocs technology to protect brine shrimp (Artemia franciscana) from pathogenic Vibrio harveyi. Journal of applied microbiology, 109(5), 1643-1649. https://doi.org/10.1111/j.13652672.2010.04791.x

Crab, R., Defoirdt, T., Bossier, P., \& Verstraete, W., (2012). Biofloc technology in aquaculture: beneficial effects and future challenges. Aquaculture, 356-357, 351-356. https://doi.org/10.1016/j. aquaculture.2012.04.046.

Dantas, E., Jr, Valle, B., Brito, C., Calazans, N., Peixoto, S. \& Soares, R. (2016), Partial replacement of fishmeal with biofloc meal in the diet of postlarvae of the $\mathrm{P}$ acific white shrimp $L$ itopenaeus vannamei. Aquaculture Nutrition 22: 335-342. https://doi.org/10.1111/anu.12249

De Schryver, P., Crab, R., Defoirdt, T. Boon, N., \& Verstraete, W. (2008). The basic of bio-flocs technology: The added value for aquaculture. Aquaculture, 277, 125-137. https://doi.org/10.1016/j.aquaculture .2008.02.019

Ebeling, J., Timmons, M.B., \& Bisogni, J.J., (2006). Engineering Analysis of the stoichiometri of photoautotrophic, autotrophic, and heterotrophic removal of ammonia-nitrogen in aquaculture system. Aquaculture, 257 , 346-358. https://doi.org/10.1016/j.aquaculture .2006.03.019

Ekasari, J., Rivandi, D.R., Firdausi, A.P., Surawidjaja, E.H., Zairin Jr, M., Bossier, P., \& De Schryver, P., (2015). Biofloc technology positively affects Nile tilapia (Oreochromis niloticus) larvae performance. Aquculture 441, 72 77. https://doi.org/10.1016/j.aqua culture.2015.02.019

Emerenciano M., Cuzon, G., Goguenheim, J., \& Gaxiola, G., (2011). Floc contribution on spawning performance of blue shrimp Litopenaeus stylirostris. Aquaculture Research, (19) : 891 - 901. https://doi.org/10.1111/j.13652109.2011.03012.x

FAO. (2018). The State of World Fisheries and Aquaculture 2018-Meeting the sustainable development goals. Rome.

Ferreira, G. Soltes, Bolívar, N. Constanza, Pereira, S. Anelise, Guertler, C., Vieira, F. do Nascimento, Mouriño, J. Luiz Pedreira, \& Seiffert, W. Quadros. (2015). Microbial biofloc as source of probiotic bacteria for the culture of Litopenaeus vannamei. Aquaculture, 448, 273 279. https://doi.org/10.1016/j.aqua culture.2015.06.006

Khatoon, H., Banerjee, S., Guan Yuan, G. Tan, Haris, N., Ikhwanuddin, M., Ambak, M. Azmi, \& Endut, A. (2016). Biofloc as a potential natural feed for shrimp postlarvae. Journal International biodeterioration \& biodegradation, 113, 304-309. https://doi.org/10.1016/j.ibiod.2016. 04.006 
Kuhn, D.D., Lawrence, A. L., Boardman, G.D., Patnaik, S., Marsh, L., \& Flick, G.J. (2010). Evaluation of two type of bioflocs derived from biological treatment of fish effluent as feed ingredients for Pacific white shrimp, Litopenaeus vannamei. Aquaculture, $\quad 303, \quad 28-33$. https://doi.org/10.1016/j.aquaculture .2010.03.001.

Lara, G., Krummenauer, D., Abreu, P.C., Poersch, L.H., Wasielesky Jr, W., 2017. The use of different aerators on Litopenaeus vannamei biofloc culture system: effects on water quality, shrimp growth and biofloc composition. Aquacult In,t 25, 147 162. https://doi.org/10.1007/s10499016-0019-8

Najdegerami, E. H., Bakhshi, F., \& Lakani, F. B. (2016). Effects of biofloc on growth performance, digestive enzyme activities and liver histology of common carp (Cyprinus carpio L.) fingerlings in zero-water exchange system. Fish physiology and biochemistry, 42(2), 457-465. https://doi.org/10.1007/s10695-0150151-9

Nimrat, S., S. Suksawat, P. Maleeweach, and V. Vuthiphandchai, (2008). Effect of different shrimp pond bottom soil treatments on the change of physical characteristics and pathogenic bacteria in pond bottom soil. Aquaculture, $285,123-129$. https://doi.org/10.1016/j.aquaculture .2008.08.020

Poli, M.A., Schveitzer R., Nuner, A.P.O., (2015). The use of biofloc technology in a South American catfish (Rhamdia quelen) hatchery: effect of suspended solids in the performance of larvae. Aquacultur Engineering, 66, 17-21. https://doi.org/10.1016/j.aquaeng.20 15.01.004
Ray, A. J.,Lewis, B. L., Browdy, C. L. and Leffler, J. W. (2010). Suspended solid removal to improve shrimp (Litopenaeus vannamei) production and an evaluation of a plant-based feed in minimal-exchange, superintensive culture systems. Aquaculture, 299, 89 - 98. https: //doi.org/10.1016/j.aquaculture.2009 .11 .021 .

Serra, F.P., Gaona, C.A.P., Furtado, P.S. et al. (2015). Use of different carbon sources for the biofloc system adopted during the nursery and grow-out culture of Litopenaeus vannamei. Aquaculture Internation al, 23, 1325-1339.

https://doi.org/10.1007/s10499-0159887-6

Ulloa Walker, D.A., Suazo, M.C.M., Emerenciano, M.G.C., 2020. Biofloc technology: principle focused on potential species and the case study of Chilean river shrimp Cryphiops caementarius. Reviews in Aquaculture. 1-24. DOI: https://onlinelibrary.wiley.com/doi/a bs/10.1111/raq.12408

Usman, Palinggi, N.N., Harris, E., Jusadi, D., \& Supriyono, E., (2011). Pengaruh manajemen pemberian pakan terhadap pemanfataan bioflok untuk pertumbuhan ikan bandeng. $J$. Ris. Akuakultur, 6(3), 433-445. http://dx.doi.org/10.15578/jra.6.3.20 $11.433-445$

Xu, W.J., \& Pan, L.Q., (2012). Effect of bioflocs on growth performance, digestive enzyme activity and body composition of juvenile Litopenaeus vannamei in zerowater exchange tanks manipulating $\mathrm{C} / \mathrm{N}$ ratio in feed. Aquaculture, 356-357, 147-152. https://doi.org/10.1016/j.aquacultur e.2012.05.022 